\title{
Kontekstualisering as hermeneutiese vraagstuk
}

\author{
E Engelbrecht \\ Hervormde Teologiese Opleiding
}

\begin{abstract}
Contextualisation as hermeneutical question
\end{abstract}

Christian proclamation has always been aware of the need to apply its message meaningfully. As such, contextualisation is a hermeneutical question proper. In modern times contextualisation is given a special meaning. It now refers to meaningfulness in a political context. This critical political paradigm asks why the oppressed receive so little attention in Western theology. This study gives relief to several motifs of the Reformation. A basic pattern is developed in such a way that it is able to establish questions about horizontal love and a just social structure as an important facet of theological reflection.

\section{INLEIDING}

'n Belangrike kenmerk van die Christelike prediking is dat die Woord in die prediking ook toepaslik toegepas word. Hierdie kenmerk hou verband met 'n belangrike kenmerk van die Christelike geloof, naamlik dat geloof ook prakties is. Met hierdie opmerking het ons alreeds by die saak van kontekstualisering uitgekom. Die sogenaamde eie teologie van die verskillende Bybelskrywers is dikwels 'n toepaslike toepassing van die evangelie vir hulle eie dag. Al sou 'n mens hoe grondig met Schleiermacher verskil, moet erken word dat sy teologie 'n meesterlike poging is om die Christelike godsdiens in die wetenskaplike wêreld van sy dag toepaslik toe te pas. Die teologiese Rasionalisme het sy teologie in harmonie met die wêreldbeeld van die sewentiende eeu ontwikkel. Ten spyte van die kritiek teen dié denksisteem, kan sy invloed nog steeds in die negentiende eeu gesien word (vgl Barth 1960: 384).

Die hele kwessie van 'toepaslik toegepas' impliseer natuurlik dat die vorm van die evangelie verstaanbaar vir die eie dag moet wees. Sommige teoloë is, ten onregte, van oordeel dat ook die inhoud vir die eie dag aanvaarbaar moet wees. Laasgenoemde oogmerk met 'toepaslik toegepas' loop dikwels op apologie wit. 
Schleiermacher wil vir die Christelike godsdiens plek inruim in 'n wetenskaplike wêreld waarin die Rasionalisme 'oorwin' en 'afgesluit' is. Hy aanvaar hierdie wêreld as wettige werklikheid. Hierom praat hy nie net die taal van hierdie wêreld nie, maar aanvaar hy ook die resultate en implikasies van hierdie wetenskaplike wêreldbeeld. Maar om vir die Christelike godsdiens 'n plek te kry, moet hierdie wêreldbeeld apologeties gekuil word sodat die Christelike in hierdie natuurlike breuk ingevoeg kan word. Die mense in Duitsland was teen die einde van die Aufklärung vermoeid deur die Rasionalisme en ontnugter deur die verloop van die Franse Rewolusie (Cragg 1970: 254). Hierdie breuk het Schleiermacher met groot insig raakgesien en op meesterlike wyse benut. Die ontsaglike invloed van die Rasionalisme en die Aufklärung op veral wetenskaplike denke, het meegebring dat die toepaslike toepassing van die Woord vir eeue lank die Aufklänung in die oog gehou het. Die konteks wat die teologie, wat min of meer kerklik gebonde was, voor oë gehou het, was veral die wetenskaplike en filosofiese wèreld.

Die Piëtiste in Duitsland en die Metodiste en Evangelicals in Engeland, daarenteen, het tydens die agtiende eeu die Woord toepaslik toegepas vir die gewone man op straat, wat dikwels ook 'n besondere arm mens was (vgl Cragg 1970: 147). In Engeland was veral die Evangeliese herlewing binne die Anglikaanse Kerk en die sektariese groepe die hoofdryfvere in die beweging om slawerny afgeskaf te kry. Die uiteenlopende teologieë van die Rasionalisme en die Piëtisme word goed verklaar vanuit hulle uiteenlopende opvattings oor wat die kernprobleem van die eie tyd is en wat die eietydse omstandighede van die teologie eis.

Verstaanbaarheid is natuurlik 'n voorvereiste vir toepaslikheid. Die eerste fase van toepaslikheid is dan ook verstaanbaarheid. Met die eerste oogopslag lyk dit of dit hier gaan oor die formele sake wat 'n bydrae tot verstaanbaarheid kan maak. Om verstaanbaar te wees moet die teologie gelokaliseer word. Hiermee word bedoel dat die teologie nie as 'n onbekende stuk vreemdheid in 'n kultuur moet lê nie, maar die taal en voorkoms van die gemeenskap wat hy wil dien, moet aanvaar. Met die eerste oogopslag lyk dit na 'n maklike onderneming, amper net so maklik as om kleredrag vir Afrika te 'localise' deur 'n los hemp met ingewikkelde kleurpatrone te ontwerp of soms ook te dra. So maklik is dit nie. Meer mense is al 'n bietjie ongeduldig omdat die Hervormde Kerk in Suidelike-Afrika nie die erediens lokaliseer deur die tipiese Afrika musiek te benut nie. Die Westerling dink dan aan dromme, handgeklap en dans. Die Afrikamens is egter dikwels bewus dat hierdie vorm van lokalisering die deur oopmaak vir ongeordende geesdrywery. Die formele is dus, meer dikwels as wat vermoed word, ook aan 'n bepaalde inhoud geknoop.

As verstaanbaarheid die eerste fase van toepaslikheid is, dan is die tweede fase die wyse waarop die inhoudelike motiewe van die konteks benut word. Vroeë 
sendelinge het die Zoeloenaam uMvelingangi vir die transendentale God verwerp en 'n nuwe godsnaam, uNkulunkulu geskep. So het 'n nuwe God, die God van die Bybel te staan gekom teenoor 'n ou god van die Zoeloegodsvoorstelling, die skeppergod-wat-voor-die-begin-daar-was. Was die verwerping van die naam en die inhoud van die naam uMvelinqangi 'n gelukkige besluit? Beslis nie! Hierdie 'beslis' kan ook verkeerdelik naief bedoel word. In die Zoeloegodsvoorstelling is uMvelinqangi die god wat hom totaal van die wêreld onttrek het. Hierdie vakuum suig nou die amadlozi (dwalendegeeste) en die amathongo (geeste wat tuis gekom het) in. Kan hierdie elemente behou word? Beslis nie! Hoe die evangelie bloot reformerend op hierdie diepgewortelde stuk kultuur moet inwerk, is moelik voorstelbaar. Die evangelie sal hier eerder vernietigend moet inwerk deurdat die bekeerling uit hierdie kultuur hierdie voorstelling volledig verwerp.

\section{KONTEKSTUALISERING AS BREē HERMENEUTIESE VRAAGSTUK}

Op die klank van veral die onmiddellike voorafgaande, sou gesê kon word dat kontekstualisering 'n Sendingwetenskaplike probleem is. Soms word dit inderdaad ook so gestel. Kontekstualisering word dan gesien as 'n wesentlike Sendingwetenskaplike probleem (Nicholls 1987: 10). Schleiermacher, egter, is seker die sprekendste bewys dat kontekstualisering 'n hermeneutiese probleem is. Sy teologie en lewe kan kortliks beskryf word as die gestaltegewing aan sy begeerte dat die Christelike godsdiens die voortou moet neem (Barth 1960: 387v) in die skepping van die moderne kultuur. Om verder onderbou te verleen aan die stelling dat kontekstualisering 'n breë hermeneutiese probleem is, word daar gewys op die moderne gesekulariseerde Westerse mens wat alreeds in Schleiermacher se dag mooi mondig was. Hou hierdie Westerse konteks minder probleme in vir die verkondiging as die konteks van die mens van die Twee-Derde Wêreld? Die Westerse mens is besig om homself te misgis, of dalk self te bedrieg, indien hy dink dat die konteks van die Twee-Derde Wêreld groter hermeneutiese probleme aan die orde stel as sy eie kleiner, meer bekende en eenvormige Eerste Wêreld. Die hermeneutiese diskussie word veral intens gevoer binne die Protestantse teologie van ons dag. 'n Dominante oogmerk van hierdie diskussie is om aan te toon dat die betekenis wat die Bybelteks dáár in die verlede gehad het ook vir ons dag toepaslike betekenis het (Gadamer 1975: 492).

'n Baie interessante, maar ook belangrike aspek van die moderne Westerse konteks, wat uit die Aufklärung voortvloei, moet uitgewys word. Die besondere waarde van Barth se ontleding van die agtiende eeu is dat hy aantoon dat die mens van die eeu die absolutistiese mens was. Barth (1960: 54) sien tereg die eintlike van dié mens as die naïewe en sterk oortuiging van die meerderwaardigheid van die 
menslike selfbewussyn, teenoor letterlik alles wat daarbuite bestaan. Die menslike selfbewussyn staan as absolute meester teenoor alles. Hy omvorm en drapeer alles, ook homself. Hy maak homself langer (trek hoëhakskoene aan), omvorm sy kultuur, die natuur en die hele werreld. Hierdie absolute magsmens deins nie terug vir sy wêreld wat dramaties groter geword het nie, maar hy neem hierdie wêreld in besit en buit hom uit. Hierdie uitbuiting sluit ook mense in en die slawehandel en slawebesit word die aanloklikste van oorsese bedrywighede.

'n Mens sou die Rasionalisme miskien nog kon beskryf as die sleutel tot die verstaan van die sewentiende eeu, maar van die agtiende eeu sou dit nie meer waar wees nie. Hier is die absolute mens die sleutel tot die verstaan van die Europese mens. Hierdie absolute mens is ook die sleutel tot die verstaan van die Deklarasies van Menseregte van die agtiende eeu. Barth (1960: 32) beskryf die twee hoofdeklarasies van dié eeu dan ook as verwilderde Calvinisme en verwilderde Katolisisme. James Cone, as Swarte, voel hierdie verwildering aan eie lyf en ervaar dat die Amerikaanse Deklarasie nie vir Swartes bedoel is nie. In dié tyd en soms ook vandag, funksioneer die Christelike etiek dus binne 'n raamwerk waarin menseroof nie as oneties beskou word nie en waarin die Swarte nie op menseregte geregtig is nie.

Die Rasionalisme van die Verligtingseeu is skynbaar filosofies gou oorwin. Die absolutisme van die agtiende eeu loop met toenemende felheid deur na die negentiende en twintigste eeue. 'n Mens sou kon dink dat die Marxisme 'n einde wou maak aan die absolute mens van die Aufklärung deur die mag te verskuif na die reglose en besitlose mens. ' $n$ Mens sou kon dink dat hier uiteindelik 'n poging was om 'n einde te maak aan die onmenslike menslikheid van die dominerende absolute mens van die agtiende eeu. Marx het aan die motiewe van die agtiende eeu geskuif, maar die grondmotief van die tyd het, ook in sy sisteem, vas bly staan. Sy subjek van dominering het slegs verskuif. Dit is die reglose en besitlose wat as mens, bewus van sy regloosheid, nou te staan kom teenoor die ganse wêreld en hierdie ganse wêreld buite sy bewussyn radikaal omvorm. Die absolute mens het nou slegs die reglose mens geword. Hierdie absolutisme het tot gevolg dat medemenslikheid in die sisteme wat hulle graag op Marx beroep, 'n relatiewe rol speel. Die absolutisme is vandag nog steeds die paradigma waarvolgens die wetenskap deur die tegniek die aarde en die menswêreld beheers. Alles moet benut en desnoods uitgebuit word. Die absolute mens staan as dominant teenoor die aarde en die menswêreld. Wetenskaplikes wat bang begin word dat ons nou die aarde gaan 'opgebruik', stel al hoe meer ' $n$ nuwe paradigma voor vir aardbenutting. Die mensbewussyn moet dan nie teenoor alles staan nie, maar die mens moet bewus wees dat hy 'n integrale deel van 
alles is. Of Kapitalistiese en Sosialistiese absolutisme met hierdie verskuiwing baie gelukkig gaan wees, is werklik'n ope vraag.

Die eintlike onreg van die Aufklärungmens teenoor die mens van die TweeDerde Wêreld, is die min begrip, meelewing en respek vir die eie-aardigheid van hierdie mens. Hierdie selfde dikkophouding bepaal dikwels ook die Kommunistiese en Kapitalistiese houding tot veral Afrika.

\subsection{Kontekstualisering}

Die woord kontekstualisering is in moderne konteks nogal swaar belas. Die woord verskyn eintlik eers op die toneel nadat dit vir die 'eerste keer' in 1972 gebruik is deur S Coe en A Sapaezian, toentertyd direkteure van die Theological Education Fund (Nicholls 1979: 21). Met hierdie woord verwys hulle na al die sake wat tot dusver deur die woord inheemswording weergegee is. Hulle voeg egter 'n tweede element by. Hulle verwys nou met kontekstualisering na 'n konteks waarin sekularisasie, tegnologie en die stryd om bevryding en geregtigheid 'n leidende rol speel. Hierdie laaste konteks, so meen hulle, karakteriseer die historiese oomblik van die Derde Werreld-situasie (Nicholls 1979: 21).Daar het egter'n merkbare progressie in die verwysing van die woord ingetree. Kontekstualisering verwys dan binne die kritiese politieke paradigma al meer na die tweede element wat so pas genoem is. Kontekstueel verwys nou na die stryd om onderdruktes te bevry. Om hierdie progressie se verwysing te verstaan, is dit nodig om eers kortliks aandag te gee aan die kritiese politieke paradigma.

Hierdie paradigma ontstaan teen die middel van die jare 1960, omdat veral in ekumeniese kringe geglo word dat die paradigma van die tradisionele teologie nie meer voldoende is om moderne vraagstukke te beantwoord nie. Hierdie teologie beoordeel die moderne konteks as een wat rewolusioner bepaald is. Die nuwe teologie het nou twee opdragte. Eers moet daar 'n rewolusie in die teologie plaasvind deur die ontwerp van 'n nuwe hermeneutiek waarin die konteks 'n sleutelrol in die uitleg en toepassing van die Skrif speel. Die tweede opdrag is dan die daadwerklike bevryding van die onderdruktes op 'n rewolusionère wyse. Om kontekstueel te wees moet die teologie prakties wees, en prakties beteken rewolusionêr-bevrydend. Dit is dus duidelik dat grondliggend aan hierdie nuwe paradigma 'n eie hermeneutiek lê. Die belangrikste elemente van hierdie hermeneutiek is, soos reeds gesê, dat die konteks die eintlike vrae aan die teologie stel én dat die konteks ook 'n wesenlike bydrae lewer tot die beantwoording van dié vrae. Die kontekstuele bepaal dan nie alleen wat relevant is nie, maar ook wat omtrent die omstandighede gedoen moet word. Omdat die konteks, dit wil sê die onderdrukking, 'n sleutelrol in die 
hermeneutiek van die nuwe paradigma speel, is blote nadenke oor die omstandighede altyd vervreemde nadenke. Hierdie vervreemding kan alleeen oorbrug word as daar iets omtrent die onderdrukking gedoen word. Dit is te begrype dat indien die hart van die konteks as rewolusioner bepaal word, daar moeilik in die proses van kontekstualisering plek kan wees vir inheemswording of sending in die tradisionele sin. Daar word hier eerder op die sosio-politieke gefokus.

Die bekende radikale Swart teoloog, J Cone (1986: 152), stel dat die kerk in Afrika so gestruktureer moet word dat dit 'n sigbare instrument van Afrikabevryding word. Derde Wêreld-teologie moet bevryding beklemtoon en nie inheemswording nie (Cone 1982b: 109). Nicholls (1987: 102) is dus heeltemal reg as hy sê dat kontekstualisering die manier is waarop verpolitiseerde teologie beoefen word. Uit die voorafgaande word dit so stadigaan duidelik dat die parameters van toepaslike toepassing, hermeneuties bepaal word. 'n Eie hermeneutiek wat op sy beurt weer deel vorm van 'n grondliggende patroon, bepaal wat 'n besondere teologie onder toepassing verstaan. Indien die persoonlike, bevrydende ontmoeting met Jesus, byvoorbeeld, nie slegs 'n element op die oppervlakstruktuur van 'n teologie is nie, maar na die dieptestruktuur verskuif, sal wat as toepaslik beskou word wesentlik verander. Toepaslik sal dan uitsluitlik verstaan word as meedeling van Jesus en van my eie ontmoeting met Hom (vgl Glasser 1987: 54). Die godsdienspatroon van 'n besondere teologie, as grondliggende koördineerder van dié teologie se motiewe, bepaal nie alleen watter elemente van die Bybel toepaslik vir die eie tyd geag word nie, maar ook die relatiewe gewig wat aan die Bybel gegee word. Tydens die Aufklärung het ook in die teologie die klem verskuif vanaf die 'buitewêreld' na die mens, van God na die mens en vanaf die Bybel na die menslike omstandighede. Dit is dus te verstane dat veral in dié tyd godsdiens 'n sleutelbegrip word. Teen dié agtergrond kan die Christelike godsdiens of die dominant wees of bloot godsdiens tusen die godsdienste of minderwaardig wees. Ook in ons dag word gestel dat daar só baie waarheid buite die kerk en die Bybel lê, en dat teologie eintlik bloot 'n simpatieke, deelnemende bedryf moet word (Kee 1977: x).

In die kritiese politieke paradigma word die tendens om aan die Bybel 'n ondergeskikte plek toe te ken, wat die inhoud en maatstaf van die toepaslike betref, al sterker (Mosala 1986a; 1986b). Wilmore (1972: 39) identifiseer op sy beurt in Afrikagodsdienstigheid ' $n$ eie-aardige element wat teen verdrukking in opstand kom. Hy is van oordeel dat die Christelike godsdiens op hierdie element (gelukkig!) geen invloed kan uitoefen nie. Die opvatting van Wilmore verskil dus blykbaar van dié van die kritiese politieke teologie. Hy lè klem op 'n tradisionele godsdienselement . Die kritiese teologie betrek die stryd van die onderdruktes op 'n omvat- 
tende wyse by die uitleg en toepassing van die Skrif en kom so o tot 'n uitleg van die Skrif wat as rewolusionêr beskryf moet word.

\subsection{Skrif en konteks}

Skrif en konteks kom in bogenoemde gevalle dus op 'n dramatiese wyse teenoor mekaar te staan. Hierdie konfrontasie is só dramaties dat 'n mens 'n paradigmaverskuiwing in albei gevalle raaksien. Die verskil tussen Wilmore en die kritiese politieke paradigma is nie radikaal nie. Alhoewel die induksie-elemente verskil, verskil die proses se eindresultate nie wesenlik nie.

Wanneer die teologie die Bybel toepaslik uitle, kan die klem uiteraard op die Bybel of die situasie val. Die verhouding tussen die Bybel en die eie situasie kan op baie verskillende maniere bepaal word. In elkeen van hierdie verhoudings sal of die Bybel of die konteks uiteindelik domineer. Die verhouding wat 'n teologie tussen die Bybel en die eie situasie konstrueer, word deur die paradigma van die betrokke teologie bepaal. Om hierdie rede is dit byvoorbeeld vanselfsprekend dat wanneer Barth (1970: 62) die verantwoordelikheid van die Christelike gemeente in die politiek bespreek, hy dit benadruk dat die norm vir hierdie betrokkenheid die Christen se eie geestelike norm is en nie die natuurlike norm waarvolgens die politiek sy sake reël nie. In die kritiese politieke teologie domineer die eie situasie. Dit is hierdie induksie-element wat hierdie teologie as praksis laat funksioneer. Die hermeneutiese vertrekpunt wat die Bybel as Woord van God aanvaar, en dus as normatief gehoorsaam, word nou as bourgeois, nu-ortodoks, onkrities en ideologiesbevange beoordeel (Mosala 1986b: 180). Die grondliggende verskil tussen die Reformatoriese en die kritiese politieke paradigma lè dus rondom hulle opvatting oor die rol van die konteks in die ontvouing van 'n kontekstuele teologie. Die Reformatoriese model dra die Skrifuitleg in die omstandighede in. Die politieke model bepaal eers die eintlike van die omstandighede. Dié is, volgens hom, rewolusionèr. Hierdie konteks word nou in die Skrifuitleg geïnduseer. Die energie wat so opgewek word, word prakties aangewend om die toestand van onderdrukking te vernietig. Kritiese politieke teologie veroordeel die Westerse teologie omdat laasgenoemde nie verdrukking teenstaan nie en die verdruktes uit die oog verloor. Die oorsaak van hierdie tekortkoming word nie bloot as 'n etiese mankement beroordeel nie, maar as paradigma-verlamming veroordeel (Cone 1982: 119, 136).

Die krities-politieke teologie le baie klem op praksis. Praksis beteken hier, net soos in die geval van Marx, dat die teorie vanuit die praktyk ontwerp word om meer suksesvol prakties te word. Hierdie eindresultaat word dan weer opnuut in die teorie ingedra. Dat die teologie uiteindelik 'n praktiese aangeleentheid is, sal 
sekerlik deur baie erken word. Dit is nie die eintlike kwessie nie. Die eintlike vraag is wat as die parameters van die praktiese geneem word. Ook hierdie vraag word bepaal deur die grondliggende hermeneutiek van 'n teologie. Volgens die paradigma van die kritiese politieke teologie kan slegs die praktiese bevrydend wees en die wyse om hierdie bevryding te bereik, slegs rewolusionêr. Die subjek van al hierdie bedrywighede is die onderdrukte.

\section{3. 'N ALTERNATIEWE PARADIGMA?}

Die kritiese politieke teologie vra voortdurend aan die Westerse teologie waarom hierdie teologie so min aandag aan onreg en verdrukking gee. Vanuit ons moderne konteks, waarin ook die Westerse teologie leef, is hierdie vraag relevant. Schulze (1985: introduc) beskryf die moderne leefwèreld tereg as 'n kleiner-wordende wêreld waarin mense al meer bewus word van die ellendes in die wêreld. Die opvatting heers dat al hierdie ellendes eintlik deur onreg veroorsaak word en die Sosiale Etiek word daarom toenemend 'n oproep tot gelyke verdeling van voorregte en besit. Bogenoemde kritiese vraag bly dus relevant, al is die begrip 'Westerse teologie' daarin swak omskryf en die 'so min aandag' swak gefundeerd. Dit is juis konserwatiewe teoloë wat dikwels ook hierdie kritiese vraag, uit heeltemal ander gronde, vra. Boshoff (1980: 123) vra of ons nie 'n belangrike faset in ons teologiese beoefening uit die oog verloor het nie. Indien dit die geval is, vra hy, roep dit dan nie om 'n bepaalde reaksie nie? Speidel (1987: 249) is van oordeel dat die politieke teologie sosiale, hermeneutiese en teologiese vrae aan die orde stel. Schulze (1975: 52) is van mening dat die Swart Teologie ons die onbetaalde rekening aanbied van koloniale uitbuiting, veragting van swart mense en gebrek aan liefde, respek en opregtheid in menseverhoudings. Hierdie vrae roep inderdaad tot noukeurige beantwoording.

Die vraag is nou of die Reformatoriese grondpatroon hierdie situasieprobleem kan beantwoord? Moet ons nie maar die Reformatoriese paradigma weggooi en 'n nuwe paradigma ontwerp wat meer kontekstueel is en dus op die moderne probleme 'n antwoord kan gee nie? Die antwoord hierop is dat die Reformatoriese grondpatroon in staat is om 'n sinvolle antwoord op moderne vrae te gee.

'n Element van die Reformatoriese hermeneutiek wat in die huidige kontekstualiteitdebat beklemtoon moet word, is die objektiewe karakter van die evangelie. Die blye boodskap bly steeds vreemd aan ons omstandighede. Hiermee word bedoel dat die Woord van God ons van buite ons eie situasie aanspreek. Dit is alleen wanneer die Woord objektief bly, dit wil sê ons van buite ons eie situasie aanspreek, dat die Woord sy aanspraak op die menslike omstandighede kan handhaaf. 
Hierdie objektiwiteit van die evangelie is ten nouste verbonde aan die unieke karakter van die Woord, naamlik dat dit God se Woord is. Dit is vanuit hierdie agtergrond dat Calvyn (I, VII, 1) stel dat die opvatting dat aan die Skrif alleen soveel waarde toegeskryf kan word as wat die kerk bereid is om daaraan toe te skryf, 'n opvatting is wat na die verderf lei. Hierdie opvatting impliseer dat die ewige en onaantasbare waarheid van God op menslike oordeel steun. Aanvaar ons die Reformatoriese grondpatroon, sal die unieke karakter van die Woord in twee rigtings funksioneer. Die Woord sal uiteindelik die vrae uitwys wat beslissend is vir menslike bestaan. Aan die ander kant kan die menslike bestaan niks aan die betekenis van die Woord toevoeg nie. Indien die objektiewe karakter van die evangelie beklemtoon word, hou dit ook gevolge in vir Skrifuitleg. Die Westerse teologie sal daarmee rekening moet hou dat 'n besittersmentaliteit sy Skrifuitleg mag beivloed. Die Reformatoriese hermeneutiek stel dit duidelik dat die Skrif as die Woord van God hierdie verkeerde uitleg sal uitwys.

'n Verdere element in die Reformatoriese grondpatroon wat in die huidige omstandighede beklemtoon moet word, is die Godsleer. Die element wat hier herbeklemtoon word, is dat daar een God is en dat die mens Jesus Christus die enigste Middelaar tussen God en die mense is (vgl $1 \mathrm{Tm}$ 2: 5). Hierdie Godsleer het tot gevolg dat dit God se wil is dat alle mense die waarheid moet ken. Hieruit vloei verder belangrike hermeneutiese gevolge. Geen kultuur kan aanspraak maak op uitsluitlike toegang tot die waarheid op grond van gewaande meerderwaardigheid, gewaande primitiwiteit, of gewaande of werklike onderdrukking nie. Wanneer die evangelie ' $n$ kulturele kloof oorsteek, sal die subjek wat teologie beoefen dus omvattend wees. Hierdie laaste uitspraak moet as 'n fundamentele hermeneutiese uitspraak verstaan word. Hierdie fundamentele uitspraak bring verder, in die sekondêre fase van hermeneutiese uitsprake, horison ter sprake. Dit is alleen wanneer 'n mens by interpretasie betrokke is soos wat jy is, dit wil sê met jou wettige vooroordele en kulturele agtergrond, dat ' $n$ mens ' $n$ betekenisvolle bydrae tot interpretasie kan maak. Dit is alleen in so 'n betrokke interpretasie dat die eie horison bevestig of gewysig kan word (vgl Gadamer 1975: 360). Dit is alreeds geste) dat die Reformatoriese paradigma dit beklemtoon dat die Woord objektief moet bly. Alleen só kan die Woord sy aanspraak op ons lewe behou. Maar ook alleen só kan die Woord troos vir ons situasie bring.

Dit bring ons by 'n derde element van die Reformatoriese grondpatroon wat reliëf behoort te ontvang in die proses om dié teologie vir ons dag relevant te maak. Hierdie element is die dienskarakter van die Woord. Hiermee word ook die dienskneggestalte van Jesus onderstreep. Wanneer hier beklemtoon word dat Jesus mens is, is dit nie sy menslike natuur wat eintlik beklemtoon word nie, maar sy 
dienskneggestalte. Dit is nie eintlik vrae oor syn wat hier ter sprake kom nie, maar vrae oor verhouding. Esser (1979: 27) toon aan dat Calvyn dit duidelik stel dat die beeld van God, wat Christus betref, verstaan moet word in terme van verhouding en nie soseer in terme van syn nie. In Christus as spieël, kan ons God se glorie, geregtigheid, goedheid en wysheid sien. En tog sien ons nie slegs 'n ietsie van God nie, maar God self. Calvyn stel dit duidelik dat God se transendensie, dit is sy vryheid as God, buite diskussie staan. Dit is egter nie hierdie vryheid wat ter sprake kom in die beeld-van-God-tema nie. Die tema wat hier ter sprake kom, is die pro nobis, dit wil sê God se toegeneentheid teenoor sy mens. Wat die mens betref, beteken sy skepping na die beeld van God, dat die mens waardig gemaak is om te erken dat Christus die onsienbare God verteenwoordig. Hiermee word God se majesteit ook erken, wat tegelykertyd 'n erkenning is dat God die God is wat vir ons is. Hier is ons by die hart van die Reformatoriese teologie (Esser 1979: 29). Indien aan die drie bogenoemde elemente relief gegee word, sal die gevolge hiervan dwarsdeur die teologie loop. Die teologie sal, onder andere, op 'n omvattende wyse ook op die onderdruktes, regloses en armes fokus. Dit gebeur inderdaad in die teologie van Calvyn. Schulze (1985) wys tereg op die gedetailleerde aandag wat die 'Sosiale Etiek' in die Etiek van Calvyn ontvang. Calvyn het nie alleen die sosiaal-etiese implikasies van die geloof getrek vir die persoonlike vlak nie, maar die implikasies ook deurgetrek na strukture.

Die teologiese fundering van die horisontale liefdesopdrag, wat die verkondiging van die evangelie en die opdrag tot medemenslikheid insluit, kom byna algemeen in die Nuwe-Testamentiese tradisies voor. In die Matteusevangelie sluit die begrip geregtigheid die opdrag tot sending en medemenslikheid in. In dié Evangelie word geregtigheid gefundeer deur die Christologie waarin Jesus veral verkondig word as God-by-ons. Die dieptestruktuur van dié Evangelie word dus deur 'n teologie gedra waarin God in die mensbestaan intree en die hele wêreld uitnooi na 'n verbond met Jesus (vgl Engelbrecht 1985: 76-81). Ook Paulus fundeer in Romeine 15: 8 die eenheid van die gemeente, wat uit die heidene en uit die Jode deur God geroep is, op die Godsleer. Ook hier word God se toegeneentheid onderstreep. Wat Israel betref, word klem gelê op God se verbondsbetroubaarheid. Wat die heidene betref, word die klem gelê op God se barmhartigheid. Hierdie soewereine ontferming van God in Christus oor Jood en heiden skep kontinuiteit tussen die Verbondsvolk en die kerk. Die implikasies hiervan is dat die evangelie aan Jode en aan heidene verkondig word en dat Jode en heidene mekaar in die kerk van Jesus Christus aanvaar (Engelbrecht 1986: 148v). Ook in Fillipense 2 motiveer Paulus vanuit die Teo-logie die opdrag tot liefde tussen die gemeentelede. In dié 
Godsleer val die klem op ontlediging, slaafgestalte, mensgestalte, vernedering en gehoorsaamheid.

Dit is duidelik dat die voorafgaande impliseer dat die Reformatoriese paradigma herbeklemtoon moet word om ' $n$ relevante woord in ons huidige omstandighede te spreek. Hierdie herbeklemtoning vind by die absolute basis van die paradigma plaas - by die Godsleer. Hierdie herbeklemtoning het dan tot gevolg dat die horisontale liefdesopdrag, medemenslikheid asook die daarstel van 'n regverdige sosiale struktuur, 'n vaste deel van die teologiese besinning en etiese praktyk sal wees.

\subsection{Kontekstueel en inheems}

Die moderne verwysing van kontekstueel plaas die begrip dikwels teenoor inheems (vgl Boshoff 1980: 129). Inheemswording, as kulturele bedryf, het volgens hierdie opvatting te make met iets wat in die moderne tyd betekenisloos geword het. Kontekstueel moet dus alleen na die sosiale verwys in die sin van die politieke en die ekonomiese. Die kritiese politieke teologie interpreteer die huidige wêreldsituasie as rewolusionêr. Kontekstualisering kan dus alleen rewolusionêr-bevrydend verwerklik word. Kontekstualisering word nou die manier waarop verpolitiseerde teologie bedryf word (Nicholls 1987: 102 \& Haight 1985: 17). Daar is min geleerdes wat die sosio-politieke aspek van die huidige omstandighede ontken. Die situasie van die Twee-Derde Wêreld moet egter nie oorvereenvoudig word nie. Die reuse omvang van die Swart Independente beweging (30\% van alle Swartes in SuidAfrika) is ook 'n aanduiding dat die inheemse kultuur nog geensins sy lewenskragtigheid verloor het nie. Sommige beoefenaars van die kritiese politieke teologie is gefrustreerd omdat die toekoms wat hulle voorsien het, nie 'n werklikheid geword het nie (vgl Boshoff 1980: 53). Het die swak aanklank wat hulle kontekstualiseringsprogram by die massa vind nie dalk sy grond in hulle ignorering van kultuur of in die feit dat hulle te veel aspekte van die inheemse kultuur afskryf as versteend nie?

Om kontekstueel, betekenisvol of relevant te wees, moet die teologie, en dus ook die teologiese etiek, beide die kulturele en die sosio-politieke aspekte van ons moderne samelewing in sy perspektief verreken. Kontekstualisering as vertaling van die evangelie vir 'n besondere situasie, veronderstel 'n wisselwerking tussen die teks en 'n besondere konteks. Die redusering van die konteks sal dus noodwendig uitloop op 'n vertaling wat net gedeeltelik verstaanbaar of aanvaarbaar is. As sulks is kontekstualisering nie eintlik 'n Sendingwetenskaplike bedryf nie, maar 'n hermeneutiese konsep met wye implikasies. Ook godsdienspatroon kom hier ter 
sprake, omdat die godsdienspatroon en hermeneutiek van 'n godsdiens ten nouste saamhang. Die godsdienspatroon sal dié vrae bepaal wat lewensnoodsaaklik vir bestaan is, asook of die konteks of die Bybel die dominant in kontekstualisering sal wees. In die grondpatroon van die kritiese politieke teologie domineer sosiale en politieke vraagstukke tot so 'n mate dat die evangelie sy objektiwiteit, dit is sy alleenaanspraak en troos, verloor. Die evangelie kan onder dié omstandighede geen selfstandige of dominante bydrae maak in die bepaling van die omstandighede nie. Die evangelie kan dan ook geen aanspraak teenoor die omstandighede handhaaf nie. Omdat hierdie politieke paradigma die hermeneutiese vertrekpunt het dat daar geen waarheid buite konkreet-historiese gebeure van die menslike bevrydingstryd is nie (vgl Nicholls 1987: 103), kan kontekstualisering slegs inhou dat die teologie 'n aktiewe rol moet speel om die omstandighede te verander. Ook die inhoud van konkreet in die bogenoemde sin word dus deur die grondpatroon van hierdie hermeneutiek bepaal. Die opvallende ooreenkomste tussen hierdie hermeneutiese vertrekpunt en die hermeneutiek van Marx is dat die kensubjek die verdruktes is en dat die vervreemding van die teorie van die werklikheid alleen deur daadwerklike optrede oorbrug kan word. In die Reformatoriese godsdienspatroon word, hierteenoor, die konteks nie só gereduseer dat sekere aspekte van die menslike bestaan nie meer van belang is, of buite die aanspraak en diens van die Woord val nie. Die teologie wat vanuit hierdie grondpatroon bedryf word, sal die konteks van die gesekulariseerde Westerse mens net so ernstig neem as die konteks van die mens in die Twee-Derde Wêreld. Dit is vanselfsprekend dat in die teologie wat volgens die Reformatoriese paradigma bedryf word, die eksegese 'n leierrol speel.

\subsubsection{Inheemswording}

Die woord inheemswording is in die moderne Sendingwetenskap nie baie gewild nie (Nicholls 1987: 102). Buthelezi (1973: 21) mag reg wees wanneer hy beweer dat Wit sendelinge se pogings om die teologie inheems te laat word, toegeskryf moet word aan 'n nostalgiese verlange na dit wat in Europese rasionalistiese teologie verlore gegaan het. Dit is egter 'n ander faset van die Romantiek wat 'n rol speel wanneer Westerse teoloë die teologie inheems wil maak. In die ware Romantiese gees word gedink dat die primitiewe die onbedorwe en die ware is. Daar is meer faktore wat die inheemswording van die teologie 'n onpopulêre bedryf maak. Een is dat Swartes soms dink dat die oproep tot inheemswording 'n poging is om die Swart politieke toekoms deur uitgediende tradisionele gebruike te manipuleer. 'n Tweede faktor is dat baie tradisionele kultuurelemente eenvoudig net nie meer lewende invloed het nie (vgl Bosch 1980: 224). Wanneer die inheemse kultuur egter konsekwent oor die 
hoof gesien word in die hermeneutiese proses van kontekstualisering, sal die eindproduk van so 'n gereduseerde hermeneutiek 'n gekunstelde voorkoms hê.

Omdat daar uit die oog verloor word dat ons hier met 'n komplekse vraag te doen het, is denke rondom kontekstualisering dikwels onbevredigend. Hierdie onbevredigende denke rondom kontekstualisering in 'n kulturele situasie wat ingrypend van die 'eie' omstandighede verskil, moet ook sovér dit die subjek van kontekstualisering betref, toegeskryf word aan 'n onbevredigende hermeneutiese vertrekpunt. Om die vraag, hoe 'n besondere gemeenskap leef en wat in hierdie gemeenskap leef, te beantwoord, moet daar noukeurig na hierdie gemeenskap geluister word. 'n Blote diakroniese ondersoek, dit wil sê 'n blote historiese ondersoek na 'n gemeenskap se geskiedenis en 'n histories-kulturele peiling is nie voldoende nie. Lewende, regte mense moet in die hermeneutiese vertrekpunt 'n belangrike rol speel. Dit beteken ook nou weer nie dat mense op een of ander vae manier 'n objek van ondersoek word nie. Die hermeneutiese vertrekpunt moet só ontwikkel word dat regte mense self ' $n$ betekenisvolle bydrae lewer om die vraag wat in hulle gemeenskap lewe, te beantwoord. Dit impliseer dat die teologie hom tuis sal moet maak en vir hom 'n tuiste sal moet skep onder die gemeenskap wat hy wil dien. Is die baie en verskillende antwoorde rondom inheemswording en kontekstualisering nie ' $n$ aanduiding dat antwoorde dikwels vir ' $n$ gemeenskap gegee word en dat hulle in die antwoord 'n ondergeskikte rol, en dan as objekte, speel nie? In die kontekstualisering van die teologie vir Afrika moet Westerse teoloë en Afrika-teoloë in fyn balans na mekaar luister. Die Westerse teoloog moet al minder antwoorde vir die Afrika-omstandighede gee en al noukeuriger luisteraar word.

Dit is alreeds gesê dat die proses van kontekstualisering soms onbevredigend verloop omdat teoloë uit die oog verloor dat kontekstualisering 'n komplekse bedryf is. Teoloë kontekstualiseer soms deur net 'n enkele of 'n paar aspekte van die kulturele situasie in ag te neem. Sundkler (1962:101) gee veral aandag aan wêreldbeeld en selfbeeld. Afrika-independente gee dikwels net aan die aspekte aandag wat steun verleen aan hulle eie ras en kerk (vgl Sundkler 1962: 105). Cone (1985: 141) beveel sterk aan dat Swart kerke wat in Afrika werk, aansluiting moet vind by progressiewe teologiese en politieke opvattings sodat bevryding die eintlike fokus word. Verder beveel hy ook aan dat die leierskap van die Afrika-kerk aan Afrika-mense oorgedra word. Soms word inheemswording op die sosiologiese vlak gesoek. Hier kan die klem wat die Afrika-kultuur op die gesin en stam lê, benut word (vgl Sundkler 1962: 109). Shorter (1985: 224) pleit weer vir 'n aansluiting by die Afrika-opvattings oor genesing. Soms word aansluiting op die liturgiese vlak gesoek en word daar veral aan ampskleredrag en musiekvorme gedink. Boesak (1978: 151) is van oordeel dat die teologie diep uit die bron van die Afrika-tradisie 
moet drink en so dit wat heilig in die gemeenskap is, vasvang, naamlik solidariteit, respek vir lewe, menslikheid en gemeenskapsbewussyn.

'n Kontekstuele of inheemse teologie moet eerder as 'n organisme beskou word waarvan nie net sommige aspekte nie, maar die totale wese sinvol ingroei in sy omgewing.

In die nuutste ontwikkeling in die Swart Teologie in Suid-Afrika is inheemswording nie meer 'n skelwoord nie. Hierdie ontwikkeling het The Institute for Contextual Theology as voog (met Frank Chikane as direkteur) en dr IJ Mosala as een van sy hoofdenkers. Mosala (1986b: 177) het duidelike hermeneutiese standpunte. Swart Teologie moet onmiddellik ophou om tussen die Woord van God en die situasie heen en weer te skarrel. Hierdie soort van teologie bedryf is 'n onbeholpe blikslaery wat niks aanmekaar gaan kry nie. Die aandrang dat die Skrif Woord van God is, is onkrities, nu-ortodoks en bourgeois. Hiermee word werklike mense uit die oog verloor, aldus Mosala. Mosala (1986a: 99) ontwerp hierteenoor 'n hermeneutiek wat fokus op die tradisionele Afrika-kultuur. Hy beklemtoon verder, as deel van die eintlike konteks en beginpunt vir 'n kontekstuele teologie, die omstandighede, die sosiale, kulturele, politieke en ekonomiese wêreld van die Swart werker en plattelander. Hy waarsku egter dat nie alle elemente van die Swartkultuur en godsdiens bruikbaar is vir 'n kontekstuele teologie van bevryding nie. Elemente sal selektief en aangepas, benut moet word. Evangelicals gee van die vroee jare negentien sewentig af besondere aandag aan die kontekstualiseringsvraag. Die woord Evangelicals verwys na 'n beweging met heelwat vlakke wat op 'n gemeenskaplike basis rus (Glasser 1987: 54). Ten grondslag van hierdie beweging lêt 'n patroon wat as elemente die erkenning van die gesag van die Skrif, redding deur genade deur die geloof, bekering as 'n duidelike ervaring, en demonstrasie van die nuwe lewe deur vroomheid het (Costas 1987: 66). Die Evangelicals grens hulle duidelik teen die radikale kontekstualisering van die Ekumeniese beweging af. Veral Beyerhaus (1974) se kritiek teen die Bangkok Konferensie (1973) was 'n belangrike motivering vir Evangelicals om 'n eie opvatting rondom kontekstualisering te ontwikkel. In hierdie opvatting speel die Koninkryk-van-God-motief 'n belangrike rol. Saam met die fokus op die Koninkryk is die Heilige Gees ook in die grondpatroon ingetrek (Glasser 1987: 61). Nicholls (1987: 105) vat die teologie wat uit hierdie grondpatroon ontwikkel, goed saam wanneer hy stel dat die kerk as die Koninkrykgemeenskap geroep is om model van die komende versoende gemeenskap te wees waarin waarheid en genade sal heers en waarin regverdiging en geregtigheid verbind sal wees. Die kerk is beide faandel en agent van die komende Koninkryk. Geestelike gawes wat in 'n verskeidenheid gegee word, maak dit vir die gemeente moontlik om sy kulturele én versoenende opdragte te volvoer. Die gevaar 
aan hierdie paradigma verbonde is dat Woord en Gees maklik van mekaar vervreemd kan raak. Die Mexico Konferensie van Evangelicals (1984) kom dan inderdaad ook tot die gevolgtrekking dat geen godsdiens die getuienis van die Heilige Gees heeltemal ontbeer nie (vgl Costas 1987: 17). Dit is verder ook 'n ope vraag of die Heilige Gees in hierdie grondpatroon nie so laat in die paradigma begin funksioneer, dat 'n mens moeilik tussen mense-agenda en Geesagenda kan onderskei nie.

Die New Evangelicals is ' $n$ erkenbare stratum in die Evangelical-beweging. Hulle organiseer in 1974 die Lausanne International Congress of World Evangelization. Die besluite van hierdie Kongres is ' $n$ aanduiding dat die invloed van die kritiese politieke paradigma nie onderskat moet word nie. Alhoewel die Evangelical-grondpatroon nie gewysig is nie, toon die uitsprake van hierdie kongres duidelike ooreenkomste met die kritiese paradigma. Tydens Lausanne word gestel dat die Sosiale Etiek gefundeer moet word op God as die Skepper en Regter van die mensdom. Die mensdom is geskape na die beeld van God en elke mens het daarom ' $n$ intrinsieke waardigheid. Bockmuehl (1979: 20) is reg as hy oordeel dat baie van die hooffigure van hierdie Kongres baie naby aan die standpunt gestaan het wat juis deur hierdie Kongres verwerp is, naamlik dat politieke bevryding ook redding is en dat sosiale optrede ook evangelisasie is. Die invloed van die kritiese politieke paradigma sal net tot skade van die kerk onderskat word.

Dit is redelik om te aanvaar dat die konteks van die Bybelse hermeneutiek van ons dag ook medebepaal word deur die kritiese politieke teologie. Hierdie teologie beklemtoon die konteks as bron, norm en einddoel van teologiebeoefening. Hierteenoor sal die Reformatoriese teologie sy hermeneutiese vertrekpunt van die Skrif alleen, weer opnuut moet beklemtoon. Vanuit hierdie vertrekpunt sal die Reformatoriese teologie aan sekere diepliggende elemente van sy paradigma reliëf moet gee. Kan die hermeneutiek in ons dag blote teorie bly? Sal die hermeneutiek hom nie veral vandag self moet toets deur prakties tot eksegese oor te gaan nie? Sal die hermeneutiek by hierdie praktiese toetsing kan bly? Behoort die Reformatoriese hermeneutiek nie ook 'n al duideliker aanwysing vir 'n praktykgerigte eksegese te gee nie. Ek is van mening dat op al hierdie vrae positief geantwoord behoort te word. Hierdie voordrag is fundering van hierdie positiewe antwoord.

\section{Literatuurverwysings}

BARTH, K 1960. Die protestantische Theologie im 19 Jahrhunderdt. Zürich: Evangelischer. 
BARTH, K 1970. Rechtfertigung und Recht: Christengemeinde und Bürgergemeinde. Zürich: EVZ.

BECKEN, H-J 1973. Relevant theology for Africa. Durban: Lutheran Publishing.

BEYERHAUS, P 1974. Bangkok 73: The beginning or end of world mission? Grand Rapids: Zondervan.

BOCKMUEHL, K 1979. Evangelicals and Social Ethics. Downers Grove: InterVarsity.

BOESAK, AA 1978. Farewell to innocence - a social-ethical study of Black Theology and Black Power. Johannesburg: Ravan.

BOSCH, DJ 1980. Currents and crosscurrents in South African Black Theology, in Wilmore, GS \& Cone, JH (eds).

BOSHOFF, CWH 1980. Swart Teologie: Van Amerika tot in Suid-Afrika Goodwood: NG Kerkboekhandel.

BUTHELEZI, M 1973. African theology and Black Theology, in Becken, H-J 1973.

CALVINUS, J 1846. Institution christianae religionis. A Tholuck (ed). London: G Thom.

CONE, JH 1982. What is Christian Theology? Encounter 43, 117-28.

CONE, JH 1985. For my people: Black Theology and black church. Johannesburg: Skotaville.

CONE, J 1986. Speaking the truth. Grand Rapids: Eerdmans.

COSTAS, OE 1987. Evangelical theology in the Two Thirds World. EvBTh 11/1,6577.

GRAGG, GR 1970. The church and the Age of Reasom, 1648-1789. Harmondsworth: Penguin.

ENGELBRECHT, E 1985. Sending en geregtigheid in die Matteusevangelie. Ongepubliseerde DD-proefskrif, Universiteit van Pretoria.

ENGELBRECHT, E 1986. Die verwysing van 'huper eleous' in Romeine 15:9. HTS 42/1, 134-50.

ESSER, HH 1979. Menschenwürde - Imago Dei zwischen humanistischem und theologischem Ansatz. HTS 35/1 \& 2, 22-40.

GADAMER, H-G 1975. Wahrheid und Methode. Tübingen: Mohr.

GLASSER, AF 1987. The evolution of Evangelical Theology since World War II. EvRTh 11/1, 53-64.

HAIGHT, R 1985. An altemative vision. Mahwah: Paulist.

KEE, A (ed) 1977. A reader in Political Theology. London: SCM.

MOSALA, IJ \& TLHAGALA, B (eds) 1986. The unquestionable right to be free:

Essays in Black Theology. Johannesburg: Skotaville. 
MOSALA, IJ 1986a. The relevance of African traditional religions and their challenge to Black Theology, in Mosala IJ \& Tlhagala, B (eds) 1986.

MOSALA, IJ 1986b. The use of the Bible in Black Theology, in Mosala, IJ \& Thagala, B (eds) 1986.

NICHOLLS, BJ 1979. Contextualization: $A$ theology of gospel and culture. Downers Grove: InterVarsity.

NICHOLLS, BJ 1987. Doing theology in context. EvRTh 11/2, 101-106.

SCHULZE, IF 1975. Die Swart teologie. In die Skriflig 9/36, $42-53$.

SCHULZE, LF 1985. Calvin and 'Social Ethics': His view on property, interest and usury. Pretoria: Kital.

SPEIDEL, TS 1987. The incarnation as the hermeneutical criterion for liberation and reconciliation. SJTh 40/2, 249-58.

SUNDKLER, B 1962. The christian ministry in Africa. London: SCM.

WILMORE, GS 1972. Black religion and black radicalism. Garden City. Doubleday.

WILMORE, GS \& CONE, JH (eds) 1980. Black Theology: A Documentary histon, 1966-1979. New York: Orbis. 